\title{
Identification of Soil Fertility Constraints of Coastal Cultivated Soils in Aghanashini Estuary, Karnataka
}

\author{
K. S. Prathibha ${ }^{1 *}$ and V. B. Kuligod ${ }^{2}$ \\ ${ }^{1}$ Department of Soil Science and Agricultural Chemistry, ${ }^{2}$ Diploma Agriculture College, \\ Konnur, University of Agricultural Sciences, Dharwad-580 005, Karnataka, India \\ *Corresponding author
}

\begin{abstract}
A B S T R A C T
Keywords

Soil fertility

constraints,

Aghanashini

estuary, Available

macronutrients and

micronutrients

Article Info

Accepted:

24 September 2020

Available Online:

10 October 2020

A study was conducted to assess the soil fertility constraints in coastal cultivated soils in Aghanashini estuary of North Karnataka district, Karnataka. Soil sampling (0-20 cm depth) was done by imposing grids of $10 \times 10^{\prime \prime}(300 \times 300 \mathrm{~m})$ intervals in the study area. The collected soil samples were analysed for $\mathrm{pH}$, EC, organic carbon, available macro nutrients, available sulphur and available micronutrients. Soils of the estuary were extremely acidic to moderately acidic with high level of soluble salts. Soil organic carbon was low to medium. The soils were low in available nitrogen and phosphorus and low to medium in available potassium and sulphur content. Among the micronutrients, iron, copper and manganese were sufficient in nature, while, zinc was sufficient to deficient in the study area.
\end{abstract}

\section{Introduction}

Coastal zone is an area of interaction between land and sea. Both marine and terrestrial environment influence this zone (Rao and Suresh, 2001). Karnataka has a coastline of $320 \mathrm{~km}$ on the Arabian Sea. Coastal region accounts for 6.09 per cent of the area of the state. Coastal zone of India assumes its importance because this region supports large human and cattle population and rich natural resources. Coastal agricultural ecosystem of the country supports the food and livelihood security of several million rural/urban poor and also contributes to the national economy in a large measure. It also supports diverse vegetation ranging from rich tropical rain forest to coastal mangroves.

Soil fertility is a dynamic natural property and it can change under the influence of natural and human induced factors. Soil fertility fluctuates throughout the growing season each year due to alteration in the quantity and availability of mineral nutrients by the addition of fertilizers, manure, compost, mulch and lime in addition to leaching. Evaluation of fertility status of the soils of an 
area or a region is an important aspect in the context of sustainable and profitable agriculture.

Low land and water productivity of this ecosystem is mainly due of the unfavourable climate and deteriorated soil health and water quality. Mahajan et al., (2015) reported that yield of rice crop in salt-affected coastal soils of Goa was poor (1.5 to $2.0 \mathrm{t}$ ha-1) due to high levels of salinity especially during the seedling and maturity stages.

Coastal soils are encountered with various abiotic stresses. Most of the coastal cultivated crop land are saline, alkaline, acid sulphate, marshy and waterlogged. Additionally, the low lying deltas are marshy and fit only for non agricultural utilization such as prawn culture. Among the existing abiotic stresses, soil salinity and acidity areas are the major cause for lower crop yield. Therefore, proper understanding about the nature, properties and prevailing constraints related to diverse group of coastal soils is necessary for developing appropriate agro-technologies for higher crop yield.

Therefore, it is critical that we increase our understanding of the soil nutrient status and relationships in the soil. An attempt has been made for identifying soil fertility constraints in coastal cultivated soils of Aghanashini estuary of North Canara district, Karnataka.

\section{Materials and Methods}

\section{Description of the study area}

The study area is Aghanashini estuary located in Kumta taluk of Uttara Kannada district of Karnataka. The Aghanashini estuary lies between $14.5208^{0}$ to $14.5393^{\circ} \mathrm{N}$ and $74.3537^{0}$ to $74.3690^{\circ} \mathrm{E}$, latitude and longitude, respectively. Aghanashini river originates in the Western Ghats (Manjguni) and flows westward towards the Arabian Sea. Major part of its course runs through forested gorges and valleys. The river meets the sea in the Aghanashini village of Kumta taluk. This river has a catchment area of $1330 \mathrm{~km}^{2}$ and it has no dam and no notable industrial establishments or major townships along its banks.

The topography on either side of the river valleys becomes more varied and irregular because of the lateritic hills and granitic terrain. The elevation ranges from 0-800 m above mean sea level (MSL). The geology of the area consists of rock formation of Archean complex consisting of Archean granites and gneisses with their sparse bands of Dharwar system of rocks are capped by laterite at many places. The climate of the area is characterized by high humidity nearly all the year round. The rainfall is plentiful with a mean annual rainfall of $2670 \mathrm{~mm}$. The major land use in the area is plantation crops followed by paddy and pulses. However, due to inundation of the marine water along river course, during non-rainy season, most of the land remains fallow. The land under waterlogging (gajani) is used for prawn cultivation.

\section{Soil sampling and analysis}

A total of 230 well distributed surface soil samples were collected from a depth of 0 to $20 \mathrm{~cm}$ in the study area (Fig. 1). The exact sample locations (latitude and longitude) were recorded during April 2018 (Pre-monsoon) with the help of a hand held GPS device.

The processed soil samples were analyzed for various parameters like $\mathrm{pH}(1: 2.5), \mathrm{EC}$ (1:2.5), soil organic carbon, available $\mathrm{P}_{2} \mathrm{O}_{5}$, available $\mathrm{K}_{2} \mathrm{O}$ and available sulphur by following standard analytical procedures (Jackson, 1973). Available nitrogen was estimated by modified alkaline $\mathrm{KMnO}_{4}$ 
method (Sahrawat and Burford, 1982). Available micro-nutrients like zinc, iron, manganese and copper were estimated by atomic absorption spectrophotometer (Lindsay and Norvell, 1978).

\section{Results and Discussion}

\section{Soil reaction $\left(\mathrm{pH}_{2.5}\right)$}

Soil $\mathrm{pH}$ in the estuary ranged from 3.64 to 6.48 with a mean value of 4.78 . Standard deviation was 0.56 and co-efficient of variation was 12 per cent (Table 1). The soil reaction in major portion of the study area was very strongly acidic in nature (Fig. 2). Skewness and kurtosis values were -0.5 and 0.3 , respectively, which indicated that the distribution of values is symmetric and the values were in narrow range and peaked towards mean. The soils of Western Ghats and coastal Karnataka are generally acidic in reaction due to intense leaching by high rainfall (Sidharam et al., 2017). The acidity of the study area is aggravated by heavy input of acidic fertilizers and lack of inputs to neutralize acidity (Kavitha and Sujatha, 2015). Unlike other salt affected soils having higher soil $\mathrm{pH}$, the coastal saline soil had an acidic soil reaction. Intrusion of salt water causes increase in the salinity levels of soil and thus both saline (high $\mathrm{pH}$ ) and saline acid soils (low $\mathrm{pH}$ ) are distinctive features of the coastal saline soils (Bandyapadhyay et al., 2003). The lateritic soils have higher degree of Al saturation and it's hydrolysis leads to prevalence of high acidity.

\section{Electrical conductivity (EC)}

The electrical conductivity of the study area ranged from 0.51 to $162.4 \mathrm{dS} \mathrm{m}^{-1}$ with a mean value of $14.51 \mathrm{dS} \mathrm{m}^{-1}$. About 2347 ha (29\% of TGA) of the study area was strongly saline and 2242 ha (27\% of TGA) was moderately saline in nature (Fig. 2). The standard deviation and co-efficient of variation were 24.26 and 167 per cent (Table 1). The data had skewness value of 2.56 and kurtosis value of 6.39. These values revealed that the data were highly skewed and more number of fields had higher values. Therefore, higher soil salinity prevailed in most of the area in the estuary. The study revealed that the lower levels of salinity at different locations may be attributed to the washing out of the salts due to heavy rainfall during the monsoon months. Besides the direct sea water intrusion, shallow and saline ground water table in the coastal region allows upward movement of salt to surface through rapid evaporation and capillary action. Thus, the salts got deposited on the upper surface of the soil, increasing the salinity of surface horizon $(0-20 \mathrm{~cm})$. These results are similar to the findings of Mahajan et al., (2015) in the coastal acid saline soils of Goa and Tripathi et al., (2006) in West Bengal coastal saline lands.

\section{Organic carbon (OC)}

The soil organic carbon content was low in major part (4812 ha of TGA) of the estuary (Fig. 3). The values ranged from 1.10 to 13.64 $\mathrm{g} \mathrm{kg}^{-1}$ with a mean value and standard deviation of 4.60 and 2.33 , respectively. The skewness and kurtosis were 0.96 and 0.64 . The co-efficient of variation was 51 per cent (Table 1). Since the soil organic matter, and consequently, the biomass and microbial activity, are generally more relevant in the first few centimeters at the surface of the soil, salinization close to the surface can significantly affect a series of microbiologically mediated processes. Due to hostile saline and acidic conditions of soils, the microbial community cannot survive. The soil salinity affects an osmotic and matric potential and thereby reduces the soil microbial activity. This further reduces the rate of organic matter decomposition, soil enzyme activities and nutrient availability. 
Similar findings were reported by Sardinha et al., (2013). Lower dose manure incorporation and poor biomass productivity under saline conditions of soil might have made the soils to be poor in organic matter.

\section{Available nitrogen}

The available nitrogen remained low in major part (71\% of TGA) of the study area (Fig. 3) similar to organic carbon. Available nitrogen content of the soils ranged from 100 to $501 \mathrm{~kg}$ $\mathrm{ha}^{-1}$. The mean, standard deviation and coefficient of variation were $217 \mathrm{~kg} \mathrm{ha}^{-1}, 67$ and 31 per cent respectively. Skewness and kurtosis values were 0.79 and 2.09 (Table 1). Low nitrogen status of the soil may be due to the low mineralization of organic matter as the soils are acidic as well as saline. It is a fact that the area receives very high rainfall (3500 mm) which results in loss of $\mathrm{N}$ due to leaching and denitrification in the soils. Therefore, the soils could retain only a limited quantity of mineralized $\mathrm{N}$. The results are in confirmation with those of Usha and Jose (1983) in laterite soils of Kerala. Mathew et al., (2009) through their extensive studies have reported that the soils of coastal agro ecosystem of Karnataka were low to medium in available nitrogen status.

\section{Available phosphorus}

The available phosphorus status varied from 2.25 to $40.56 \mathrm{~kg} \mathrm{ha}^{-1}$ with a mean and standard deviation of $10.5 \mathrm{~kg} \mathrm{ha}^{-1}$ and 5.77 respectively. The skewness and kurtosis values were 1.42 and 3.84 which indicated that the distribution of values is highly skewed and very few fields had higher values of available $P$. The co-efficient of variation was 55 per cent (Table 1). About 6129 ha (75 $\%$ of TGA) of the study area was low in available phosphorus status (Fig. 4). The soils were low in available phosphorus which might be attributed to low CEC and low clay content as revealed by Mamaledesai (2012). The low status of available $\mathrm{P}$ was also attributed to its acidic nature of soils and has high content of $\mathrm{Fe}$ and $\mathrm{Al}$ oxides and hydroxides. Fixation of the soil available $\mathrm{P}$ by $\mathrm{Fe}$ and $\mathrm{Al}$ oxides and hydroxides could be a probable reason for low available $\mathrm{P}$ (Mahajan et al., 2015). Similarly, low status of available $\mathrm{P}$ in Western Ghats was recorded by Sathisha and Badrinath (1994) and Mathew et al., (2009) in Mirjan village under the coastal agro eco-system of Karnataka.

\section{Available potassium}

The available potassium status in the study area ranged from 48 to $684 \mathrm{~kg} \mathrm{ha}^{-1}$. The mean and standard deviation were $172 \mathrm{~kg} \mathrm{ha}^{-1}$ and 113, respectively. Distribution of values was highly skewed (1.49) and too peaked (3.04). Data presented in Fig. 4 on available potassium revealed that the status was low in 5209 ha (64\% of TGA) and medium in 922 ha (11\% of TGA). The low availability of soil potassium is due to coarser texture of the soils leading to higher leaching losses of $\mathrm{K}$ (Sidharam et al., 2017). The results are in line with Sanappa and Manjunath (2013) who recorded low available $\mathrm{K}$ status in lateritic soils of coastal plain and Western Ghats of Karnataka. Further, acidic conditions create chemical environment that doesn't favour high available K content. Periodical intrusion of salt water to low lying area (along river course) enriches the soils and as a result the soil available $\mathrm{K}$ status is medium to high in some portion of the study area.

\section{Available sulphur}

The available sulphur status of soils ranged from 7 to $48.5 \mathrm{mg} \mathrm{kg}^{-1}$. The mean, standard deviation and co-efficient of variation were $18.6 \mathrm{mg} \mathrm{kg}^{-1}, 9.2$ and 50 per cent, respectively. The data had skewness value of 1.13 and kurtosis value of 3.04. These values 
revealed that the data were highly skewed and distribution is too peaked (Table 1) towards low content. Therefore, most of the fields in the study area are poor in available S content. The study area was low to medium in available sulphur status. Deficiency of sulphur is due to low $\mathrm{pH}$ and low content of sulphur bearing minerals (Anathanarayana $e t$ al., 1986). Moreover, coarse texture soil, inherent low organic matter content and soil conditions that favour sulphur leaching losses are also reasons for low available sulphur in soil (Patra et al., 2012). Medium available sulphur status in low lying area of the estuary is an expected fact, since the saline water intrusion brings in an appreciable concentration of $\mathrm{SO}_{4}{ }^{2-}$ (Mahajan et al., 2015).

Table.1 Descriptive statistics of physico-chemical properties and available macro-nutrients status of surface soil samples of coastal cultivated soils of Aghanashini estuary

\begin{tabular}{|c|c|c|c|c|c|c|}
\hline Parameters & Range & Mean & Standard deviation & C V (\%) & Skewness & Kurtosis \\
\hline pH $(1: 2.5)$ & $3.64-6.48$ & 4.78 & 0.56 & 12 & -0.50 & 0.30 \\
\hline $\operatorname{ECe}\left(\mathrm{dS} \mathrm{m}^{-1}\right)$ & $0.5-162.4$ & 14.51 & 24.26 & 167 & 2.56 & 6.39 \\
\hline$O C\left(\mathrm{~g} \mathrm{~kg}^{-1}\right)$ & $1.10-13.64$ & 4.60 & 2.33 & 51 & 0.96 & 0.63 \\
\hline Available $N\left(\mathrm{~kg} \mathrm{ha}^{-1}\right)$ & $100-502$ & 217 & 67 & 31 & 0.79 & 2.09 \\
\hline Available $P\left(\mathrm{~kg} \mathrm{ha}^{-1}\right)$ & $2.25-40.56$ & 10.5 & 5.77 & 55 & 1.42 & 3.84 \\
\hline Available K $\left(\mathrm{kg} \mathrm{ha}^{-1}\right)$ & 48- 684 & 172 & 113 & 66 & 1.49 & 3.04 \\
\hline Available $S\left(\mathrm{mg} \mathrm{kg}^{-1}\right)$ & $7-48.5$ & 18.6 & 9.2 & 50 & 1.13 & 0.11 \\
\hline
\end{tabular}

Table.2 Descriptive statistics of available micro-nutrients status of surface soil samples of coastal cultivated soils of Aghanashini estuary

\begin{tabular}{|l|c|c|c|c|c|c|}
\hline Parameters & Range & Mean & Standard deviation & $\mathbf{C ~ V ~ ( \% ) ~}$ & Skewness & Kurtosis \\
\hline Iron $\left(\mathbf{m g ~ k g}^{-1}\right)$ & $3.4-27.4$ & 10.25 & 4.4 & 43 & 1.09 & 1.43 \\
\hline Manganese $\left(\mathbf{m g ~ k g}^{-\mathbf{1}}\right)$ & $1.1-28.0$ & 5.15 & 4.10 & 80 & 2.47 & 7.86 \\
\hline Zinc $\left(\mathbf{m g ~ k g}^{-1}\right)$ & $0.2-2.70$ & 0.59 & 0.29 & 49 & 2.60 & 14.12 \\
\hline Copper $\left(\mathbf{m g ~ k g}^{-\mathbf{1}}\right)$ & $0.6-5.8$ & 1.71 & 0.98 & 57 & 1.74 & 3.21 \\
\hline
\end{tabular}

Fig.1 Location map of Aghanashini estuary

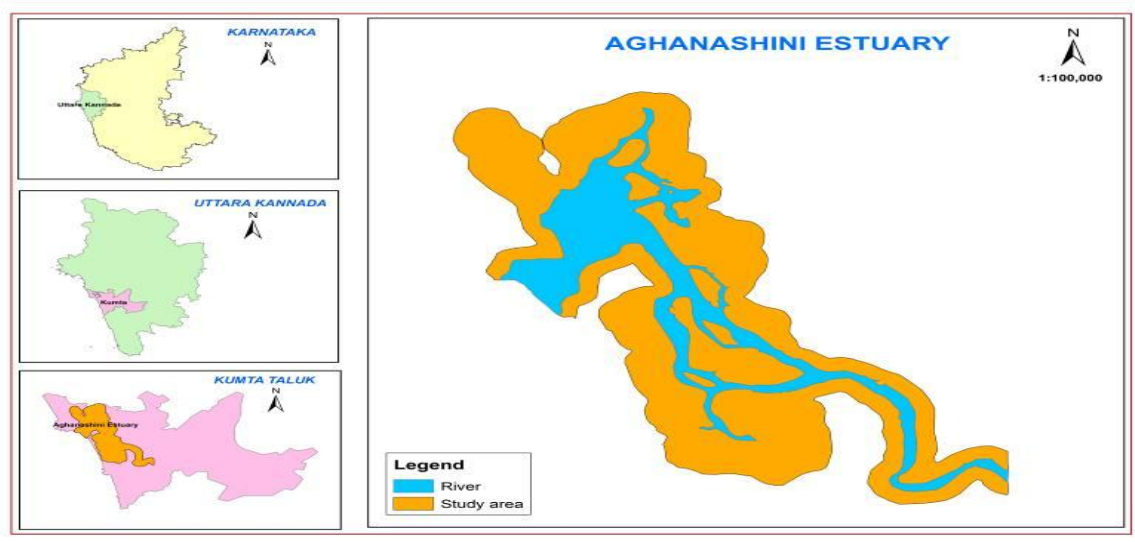


Fig.2 $\mathrm{pH}_{2.5}$ and $\mathrm{EC}_{\mathrm{e}}$ status of Aghanashini estuary
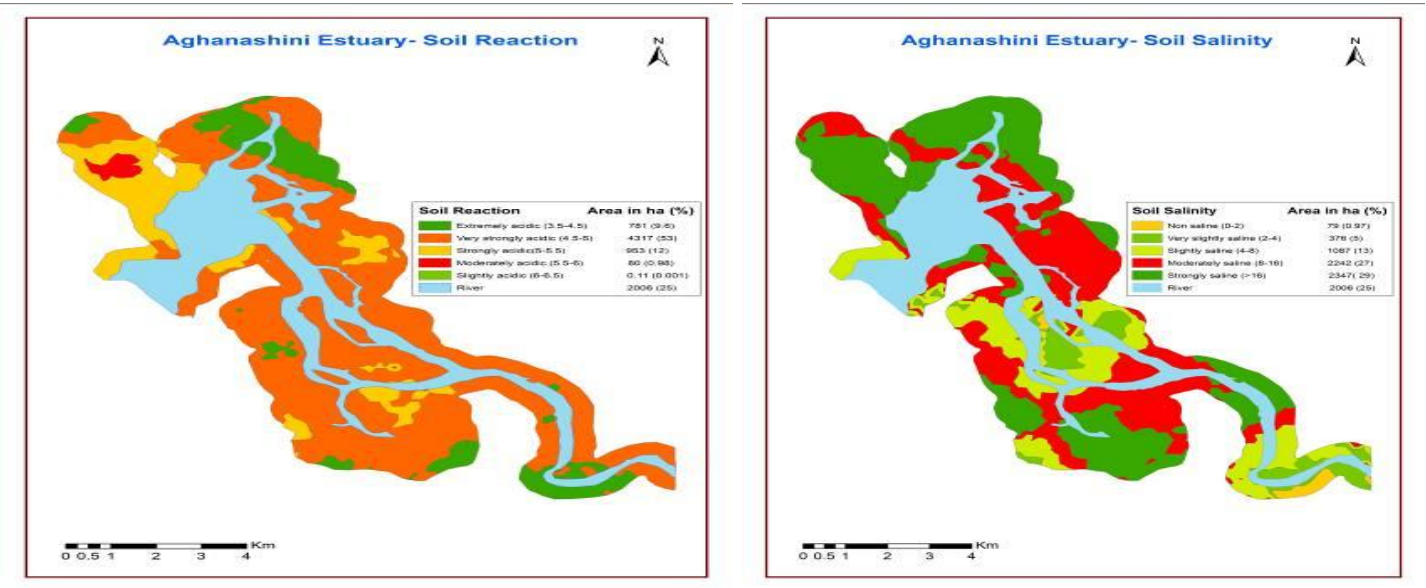

Fig.3 Organic carbon and available nitrogen status of Aghanashini estuary
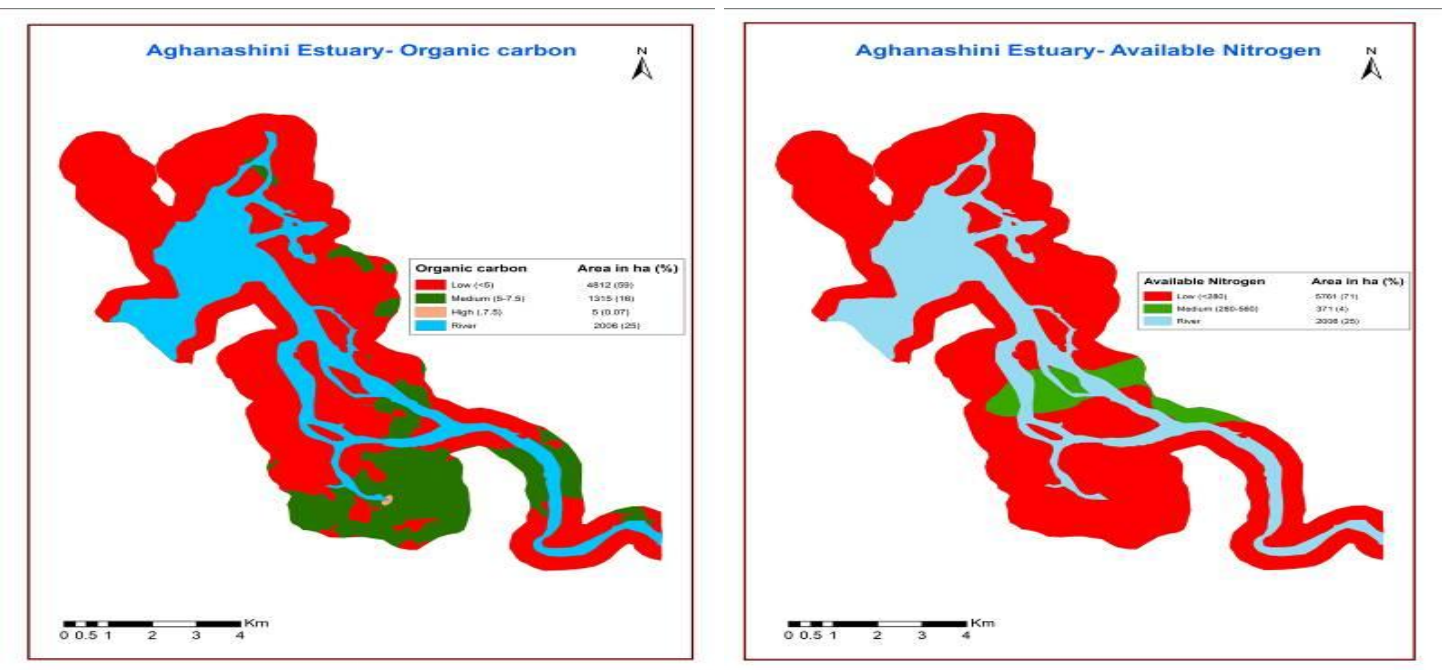

Fig.4 Available phosphorus and potassium status of Aghanashini estuary

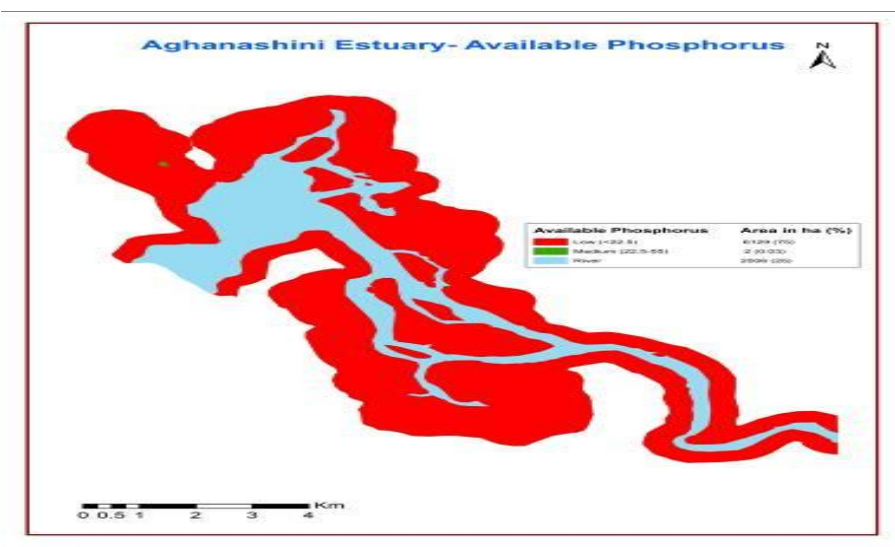


Fig.5 Available zinc status of Aghanashini estuary

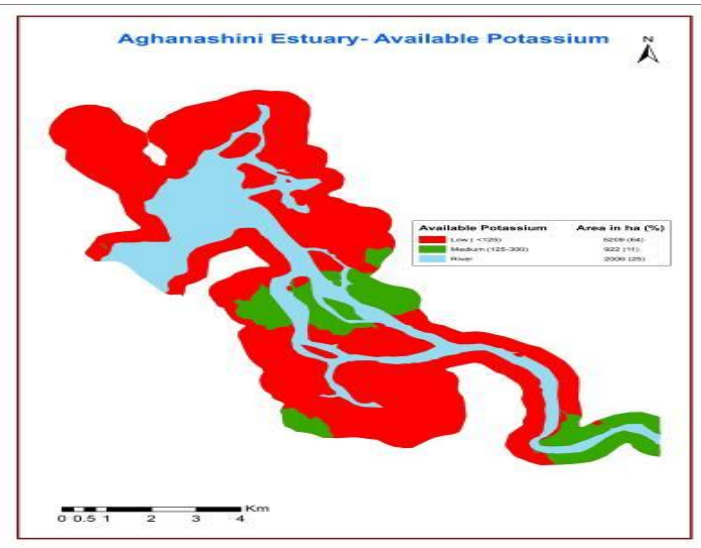

\section{Available iron}

The available iron was sufficient in the entire study area and it ranged from 3.4 to $27.4 \mathrm{mg}$ $\mathrm{kg}^{-1}$ (Table 2). The mean, standard deviation and co-efficient of variation were $10.25 \mathrm{mg}$ $\mathrm{kg}^{-1}, 4.4$ and 43 , respectively. Iron availability was highly varied due to heterogeneity among fields on account of different manuarial practice and topography. Skewness and kurtosis values were 1.09 and 1.43 which indicated that the distribution of values is highly skewed and some fields had higher values. The higher content of iron in these soils may be due to the acidic soil reaction. Similar results were also reported by Mahajan et al., (2015) in coastal acid saline soils of Goa

\section{Available manganese}

The available manganese content was sufficient in the entire cultivable area. The available manganese content ranged from 1.1 to $28.0 \mathrm{mg} \mathrm{kg}^{-1}$ with the mean of $5.15 \mathrm{mg} \mathrm{kg}^{-1}$ and standard deviation of 4.10. The coefficient of variation was 80 per cent (Table 2 ). The skewness and kurtosis values were 2.47 and 7.86 which showed that the distribution of values was highly skewed and more number of fields had extreme values. Similar to iron higher content of manganese

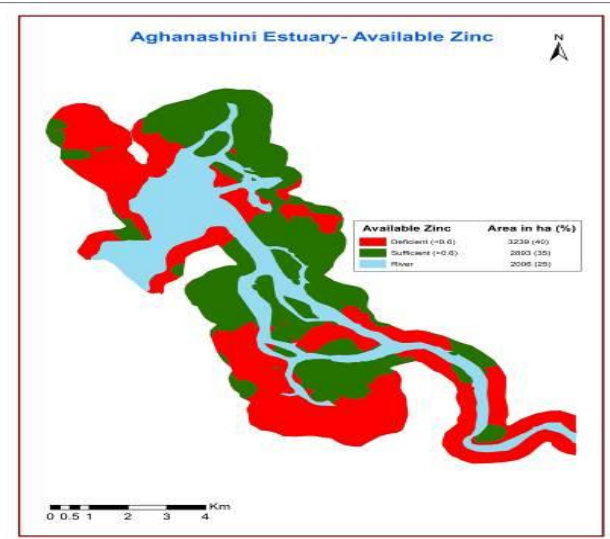

in these soils may be due to the acidic soil reaction.

\section{Available zinc}

Available $\mathrm{Zn}$ status was deficient to sufficient in the study area. Of the total area, 3239 ha (39 \% of TGA) and 2892 ha (35\% TGA) were found deficient and sufficient in Zinc, respectively (Fig. 5). The available zinc content in study area ranged from 0.2 to 2.7 $\mathrm{mg} \mathrm{kg}{ }^{-1}$ (Table 2). Whereas, the mean, standard deviation and co-efficient of variation were $0.59 \mathrm{mg} \mathrm{kg}^{-1}, 0.29$ and 49 respectively. The skewness and kurtosis values were 2.60 and 14.12 which shows that the distribution of values was highly skewed and there is a presence of extreme values in the field. The low available zinc content in the soils was attributed to the very high rainfall in the study area resulted in heavy leaching of nutrients. Similar results were also reported by Mini (2003). This element occurs as a contaminant in phosphatic fertilizers. So continuous addition of chemical fertilizers might have increased the adequate levels of zinc in these soils. The present results are in line with those of Sidharam et al., 2017 who found adequate $\mathrm{Zn}$ content in soils of Western Ghats and Coastal Karnataka under different agro-ecological systems. 


\section{Available copper}

As like manganese, the available copper content was sufficient in the entire cultivable area. The available copper content ranged from 0.6 to $5.8 \mathrm{mg} \mathrm{kg}^{-1}$ (Table 2). The mean, standard deviation and co-efficient of variation were $1.71 \mathrm{mg} \mathrm{kg}^{-1}, 0.98$ and 57 per cent, respectively. The data had skewness value of 1.74 and kurtosis value of 3.21 . These values revealed that the data were highly skewed and distribution is too peaked. About 100 per cent of the soil samples were sufficient range in available copper content. As most of soils in study area are acidic, with decrease in soil $\mathrm{pH}$ the adsorption of $\mathrm{Cu}$ to the permanent charges will decrease, which is the common phenomena making it higher available to crops (Sidharam et al., 2017)

In conclusions the present study has given an insight into the potentials and limitations of the soils of the study area. This could be used to improve the productivity and design a framework for managing the soils. Based on the soil analysis data, it was observed that soils are acidic in reaction and have high level of soluble salts. The fertility status of the coastal saline soils of Aghanashini estuary revealed that, the soils were low in organic carbon, available nitrogen and available phosphorus, low to medium in available potassium and sulphur. Among the micronutrients, iron, copper and manganese were sufficient in nature. While, zinc was sufficient to deficient in the study area. Combined application of organic amendments and inorganic fertilizers seems to be a practical solution to combat coastal soil salinity in the context of crop production.

\section{References}

Anathanarayana, R., Mithyanta, M. S. and Perur, N. G., 1986, Fertility status of the acid soils of Karnataka. Mysore J.
Agric. Sci., 8: 209.

Bandyapadhyay, B. K., Maji, B., Sen, H. S. and Tyagi, N. K., 2003, Coastal soils of West Bengal- their nature, distribution and characteristics. Bulletin No. 1/2003. Central soil salinity research institute, regional research station, canning town, West Bengal, pp. 1-62.

Jackson, M. L., 1973, Soil Chemical Analysis, Prentice Hall of India Private Limited, New Delhi.

Kavitha, C. and Sujatha, M. P., 2015, Evaluation of soil fertility status in various agro ecosystems of Thrissur district, Kerala, India. Int. J. Agric. Crop Sci., 8(3): 328 -338.

Lindsay, W. L. and Norvell, W. A., 1978, Development of a DTPA soil test for zinc, iron, manganese and copper. Soil Sci., Society American j. 42: 421-428.

Mahajan, G. R., Manjunath, B. L., Latare, A. M., D'Souza, R., Vishwakarma, S. and Singh, N. P., 2015, Fertility status of the unique coastal acid saline soils of Goa. J., Indian Soc. Soil Sci., 63(2): 232-237.

Mamaledesai, N. R., Patil, P. L., Chandrashekar, C. P., Potdar, M. P., Astaputre, S. A., Desai, S. R. and Swamy, H., 2012, Assessment of nutrients status in cotton growing area of Haveri district in northern transitional zone of Karnataka and response of cotton to applied nutrients at different yield targets. Proc. AgroInformatics Precision Agric. India, pp. 42-46.

Mathew, D. V., Patil, P. L. and Dasog, G. S., 2009, Identification of soil fertility constraints of a pilot site in coastal agro ecosystem of Karnataka by geographic information systems technique. Karnataka J. Agric. Sci., 22(1): 77-80.

Mini, V., 2003, Characterization and monitoring of soil and water resources in Mirjan village of coastal agro 
ecosystems of Karnataka. M.Sc. (Agri.) Thesis, Univ. Agric. Sci., Dharwad (India).

Patra, P., Mandal, S. and Ghosh, G. K., 2012, Status of available sulphur in surface and sub-surface soils of red and lateritic soils of West Bengal. Int. J. Pl, Ani. Envi. Sci., 2(2): 276- 281.

Rao, A. T. and Suresh, P. V., 2001, Coastal ecosystems of the Karnataka state, India I- mangroves, Karnataka Association for the Advancement of Science, Bangalore.

Sahrawat, K. L. and Burford, J. R., 1982, Modification of the alkaline permanganate method for assessing the availability of soil nitrogen in upland soils. Soil Sciences. 133: 53-57.

Sannappa, B. and Manjunath, K.G., 2013, Fertility status of soils in the selected regions of the western ghats of Karnataka, India. Sch. Acad. J. Biosci., 1(5): 200-208.

Sardinha, M., Muller, T., Schmeisky, H. and Joergensen, R.G., 2013, Microbial performance in soil along a salinity gradient under acidic conditions. Applied Soil Ec., 23: 237-244.

Sathisha, G. C. and Badrinath, M. S., 1994, Characterization of soils of western ghats in Dakshina Kannada district, Karnataka. Agropedology, 4: 45-48.

Sidharam, P. K. S., Kumar, A. and Srinivasamurthy, C. A., 2017, Soil fertility status and nutrient index for primary nutrients in western Ghats and coastal Karnataka under different agroecological systems. An Asian J., Soil Sci.,12(2): 314-319.

Tripathi, S., Kumari, S., Chakraborty, A., Gupta, A., Chakrabarti, $\mathrm{K}$ and Bandyapadhyay, B. K., $\quad 2006$, Microbial biomass and its activities in salt affected coastal soils. Bio.Fertility Soils, 42: 273- 277.

Usha, P. B. and Jose, A. I., 1983, Carbonnitrogen relationship in laterite soils of Kerala. Agric.Res. J. Kerala, 21: 15-22.

\section{How to cite this article:}

Prathibha, K. S. and Kuligod, V. B. 2020. Identification of Soil Fertility Constraints of Coastal Cultivated Soils in Aghanashini Estuary, Karnataka. Int.J.Curr.Microbiol.App.Sci. 9(10): 29622970. doi: https://doi.org/10.20546/ijcmas.2020.910.357 